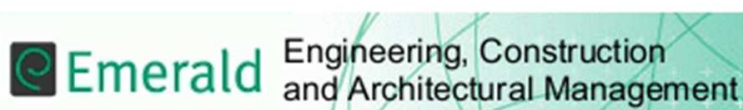

\section{Integrating value management into sustainable construction projects in Hong Kong}

\begin{tabular}{|r|l|}
\hline Journal: & Engineering, Construction and Architectural Management \\
\hline Manuscript ID & ECAM-03-2017-0049.R3 \\
\hline Manuscript Type: & Original Article \\
\hline Keywords: & Value Management, Construction, Integrated Practice, Questionaire survey \\
\hline Abstract: & \\
\hline \multicolumn{2}{|c}{} \\
\hline
\end{tabular}

SCHOLARONE ${ }^{\text {m }}$

Manuscripts 

in Hong Kong

5 Abstract

6 Purpose

7 Integrating sustainability into the value management (VM) process can provide a strategic

8 platform for promoting and incorporating sustainable design and development during the

9 lifespans of construction projects. The aim of this study was to investigate the strengths, 10 weaknesses, opportunities and threats (SWOT) for integrating sustainability into the VM 11 process in Hong Kong.

\section{Design/methodology/approach}

14 Following an extensive literature review, 45 attributes were identified and grouped into 15 Strength, Weakness, Opportunity and Threat elements. A questionnaire survey based on these 16 groupings was supported by a semi-structured interviews with public sector clients, value 17 managers and VM facilitators. They shared their experience and views on how to integrate 18 sustainability into the VM exercises.

\section{Findings}

21 The triangulated results of the survey and interviews are presented in this paper. The ranking 22 of the SWOT analysis results indicate that VM does provide opportunities for 23 multidisciplinary professionals and stakeholders to focus on issues relating to society and the 24 environment, which is considered a main strength. The major weakness of integration is the 25 lack of well-trained staff and low levels of VM participant expertise in relation to the 
26 sustainable construction issue.

\section{Practical implications}

29 There are immense opportunities for integrating sustainability into the VM process, including 30 encouragement of the reduction, reuse and recycling of construction and demolition waste.

31 However, threats presented by integration include the additional time and costs required for 32 achieving sustainability targets.

33

34 Originality/value

35 Findings and recommendations provided in this paper should be helpful to decision makers 36 including clients and VM facilitators for the successful integration of the sustainability 37 concept into the VM process.

39 Introduction

40 Buildings have a massive effect on society, the economy and the environment over their 41 entire life cycles. According to a report released by the United Nations Environmental 42 Programme (UNEP) (2009), buildings consume more than $40 \%$ of global energy and 43 contribute up to one-third of global GHG emissions in both developed and developing 44 countries. Around $40 \%$ of the total energy consumed by the U.S. and Europe is consumed in 45 residential and commercial buildings (U.S. Department of Energy 2008; Buildings 46 Performance Institute Europe 2011). Buildings consume about 90\% of the electricity in Hong 47 Kong, and alone generate around $60 \%$ of Hong Kong's GHG emissions (Council for 48 Sustainable Development 2011; Yip and Ho 2013). These have led to the development of 49 'sustainable buildings' that are environmentally responsible and resource-efficient over their 50 development processes. 
52 Brundtland (1987) defined sustainability as "meeting the needs of the present without 53 compromising the ability of future generations to meet their own needs." Kibert (1994) 54 defined sustainable construction as "creating a healthy built environment using resource55 efficient, ecologically-based principles." Sustainable construction has generally been 56 described as a process that starts before construction per se (in the planning and design stages) 57 and continues after the construction team has left the site (Hill and Bowen 1997).

58 Wolstenholme (2009) emphasised that the construction industry must be modernised by 59 adopting efficient, integrated, innovative and sustainable construction practices. Raising 60 sustainability awareness at the early onset of a project is highly encouraged, to optimise the 61 potential to determine the course of the project. Value management (VM) has the capability to 62 encompass the adoption of the sustainability concept at the conceptual and design stages of a 63 project process (Abidin and Pasquire 2003; 2007).

65 Value Management is an organised function-oriented systematic team approach directed at 66 analysing the functions and costs of a system, supply, equipment, service or facility, for the 67 purpose of enhancing its value, through achieving the required functions specified by the 68 clients at the lowest possible overall cost, consistent with requirements for performance 69 (Shen, 1993). The process may be applied to management decision making at any level of an 70 organisation and specifically may be applied to projects, products, systems, services, [and] 71 processes" (AS/NZS 4183, 1994). VM is a proactive, creative, structured, systematic, 72 analytical and multidisciplinary approach to examining project functionality and a wide range 73 of stakeholder requirements to optimise value for money at the lowest overall cost during the 74 project life cycle, from concept to use (Al-Saleh and Taleb 2010; Kelly et al. 2004). It does so 75 by reviewing the costs, quality and functions involved in the project (Myers 2013). VM 
76 studies are usually conducted during the early stages of a project to achieve the maximum

77 benefits and resource savings (Norton and McElligott 1995; HM Treasury 1996; Thiry 1997).

78 Although costs and benefits are the primary considerations of VM studies, VM is considered

79 not only a cost-cutting exercise, but rightfully a value-enhancing tool (Al-Saleh and Taleb

80 2010). The project cost should not be reduced at the expense of its functionality and

81 sustainability objectives, which would then diminish its value (Male et al. 1998; Parker 82 1998).

84 However, very few studies have investigated how to effectively integrate sustainability issues 85 into the VM process (Schneider 1999; Abidin and Pasquire 2003; Fong 2003; Abidin 2005; 86 Abidin and Pasquire 2005; Abidin and Said 2006; Abidin and Pasquire 2007; Al-Saleh, Taleb 87 2010). The strengths, weaknesses, opportunities and threats of integrating sustainability 88 issues into the VM process should be investigated in practice. This research project seeks to 89 fill this gap. The aim of this paper is to investigate the potential value of integrating 90 sustainability issues into the VM processes in Hong Kong by undertaking a SWOT analysis. 91 The major objectives are to investigate the potential for integrating sustainability 92 considerations into the VM processes by identifying integration strengths and major 93 weaknesses and by developing effective ways of creating opportunities and mitigating any 94 threats to the integration process. Effectively SWOT analysis was used to analyse the current 95 practice with respect to the integration of sustainability considerations into the VM processes 96 and to formulate strategies to make more likely the inclusion of sustainability issues at the 97 project inception stage.

99 Literature Review 
101 "The VM process is based on a facilitated participatory workshop involving a 102 multidisciplinary and representative group of people who work together and follow a 103 prescribed job plan to achieve best value or, where appropriate, best value for money for 104 projects, products, systems, services, and processes" (Standards Australia 2007, p. iv). An 105 essential element of the process is that it enables multidisciplinary stakeholders, including 106 clients, consultants, government representatives, end users and the general public, to 107 participate in briefing and design, clarify their needs, attain a better understanding of the 108 project and interests of other stakeholders, build a consensus, and create a sense of ownership 109 and commitment to the solutions that emerge from the VM workshops (Lam 1995; Kelly and 110 Duerk 2002; Yu 2007; Yu et al. 2005a,b; Yu et al. 2006a,b; Yu et al. 2007; 2008). The VM 111 process clarifies project objectives, various stakeholder perspectives and how project 112 objectives may be achieved effectively (Kirk and Spreckelmeyer 1988; Shen 1993). Although 113 its approaches may vary depending on the procurement route chosen, VM is a technique that 114 can be applied to any construction project, and take into account its functional and services 115 requirements over the entire life cycle.

116

117 Value management was first introduced in Hong Kong in 1988 (Shen and Yu 2012). The 118 Environment, Transport and Works Bureau of Hong Kong issued a technical circular 119 demanding that VM studies be carried out in the Public Works Programme (PWP) for major 120 projects with an estimated cost of more than HK\$200 million (equivalent to USD $\$ 15.6$ 121 million) (Works Bureau 2002). As the works agent for the construction of new government 122 buildings, the Architectural Services Department (ArchSD) of Hong Kong arranged a number 123 of VM studies and still takes a leading role in promoting the integration of sustainability into 124 the VM processes. The ArchSD has been taking proactive measures to uphold the 125 environmental performance of government buildings via comprehensive site planning, 
126 sustainable architectural design, the use of green and recycled materials, greenery provisions,

127 waste management, water conservation, the application of energy-efficient measures, the

128 adoption of renewable energy technologies, indoor environmental control, visual effects, low

129 running costs, user comfort and holistic green construction measures at different project

130 stages (Ho and Au 2010). At present moment, ten mega infrastructure projects announced in a

131 2007-08 policy address are being carried out in Hong Kong at a total value of HK\$49.6

132 billion (USD\$6.39 billion), and sustainability issues are being given priority. For example,

133 greening and urban connectivity are being emphasised in the Kai Tak redevelopment project

134 (Architectural Services Department 2011). Although the public sector is encouraged to adopt

$135 \mathrm{VM}$ in their projects, there is lack of record for the application of VM in the private sector.

136

137 Application of sustainability in VM

138 Topics of sustainability have been addressed by countless studies (Oke et al, 2015).

139 Transforming strategic sustainability objectives into specific actions for projects is a

140 complicated process (Aarseth et al., 2016; Marcelino-Sádaba et al., 2015). A balance needs to

141 be created between the environmental, economic and social sustainability dimensions

142 (Martens and Carvalho, 2016; Oke et al, 2015). These are considered the "three pillars" of

143 sustainable construction. Integrating sustainability at a very early stage of the construction

144 processes and throughout the project life cycle is essential to the decision making process of

145 project development and project success (Carvalho and Rabechini, 2017). The desire for

146 sustainable development and the new corporate social responsibility ethic adopted by

147 companies are drivers that may also encourage the wider use of VM at the earlier strategic

148 stages (Fewing 2005). The extent to which each of the three pillars applies to a particular

149 construction project and the decision over where to give priority depend on the value

150 judgments of the client, VM facilitator and participants. Although a trade-off is sometimes 
151 required between the different sustainability pillars, this trade-off should neither hinder 152 innovative ideas nor compromise the project cost, quality and time objectives (Hill and 153 Bowen 1997). During the workshop stage, brainstorming and group dynamics are key 154 ingredients in the successful delivery of project value for money (Langston and Ding 2001). 155 VM studies must account for different stakeholder needs and expectations. These 156 stakeholders may include senior representatives of client's managerial team, design and 157 project management team, contractor's team and end users. Economic sustainability should 158 not be separated from environmental and social sustainability in proposing alternatives and 159 solutions. In the post-workshop stage, the proposals can be accepted or rejected by senior 160 management. If the proposals are accepted, plans and strategies are formulated to implement 161 them. A conceptual framework for integration of sustainability into value management 162 process is depicted in Figure 1.

\section{[Insert Figure 1 here]}

165

166 Scholars have proposed the notion of integrating sustainability into the VM process at 167 different international conferences organised by the Institute of Value Management (Barton et 168 al. 1999; Alexandre et al. 2006; Yeomans 2002). Abidin's (2005) studies pioneered work in 169 the field. VM enables sustainability to be integrated into the design process of a construction 170 project (Abidin and Pasquire 2003; 2007). A systematic VM job plan can effectively guide 171 the inclusion of sustainability issues during the building life cycle. Although the term 172 "sustainability" may not be used frequently in VM workshops, sustainability aspects such as 173 energy efficiency, waste minimisation, healthy indoor environment, air and water quality, 174 aesthetic effects, low life-cycle costs and user comfort are commonly discussed (Abidin and 175 Pasquire 2005; 2007; Shen and Yu 2012). Sustainability considerations may differ from one 
$176 \mathrm{VM}$ workshop to another due to the client's unique requirements, commitment to

177 construction aspects, knowledge of the VM participants and time constraints involved

178 (Abidin and Pasquire 2005). For example, sustainability issues have been considered on

179 various U.K. projects such as a sustainable housing project in Crianlarich, Startfilan, where

180 VM was used to benefit the community (BRE Scotland 2001); sustainable homes and

181 facilities in Stirlingshire; and the Katrine Water Project at Loch Katrine, Scotland

182 (Stephenson 2003). The main concerns of the participants when conducting a VM workshop

183 are identifying and achieving the project objectives. Sustainability issues must be integrated

184 into VM workshops to achieve sustainability objectives (Abidin and Pasquire 2007).

185

186 The general view of the construction industry in Hong Kong is that any application of 187 environmentally friendly methods involves extra costs and effort (Shen and Tam 2002).

188 Earlier researchers have identified practical barriers, including time limitations, the absence

189 of sustainability standard guidance and behavioural barriers such as lack of knowledge and 190 awareness of sustainability among VM participants, and conflicting perceptions among VM 191 practitioners of how sustainability should be integrated into the VM process (Abidin and 192 Pasquire 2005; 2007). Previous studies have focused on investigating the integration of risk 193 management with VM (Hiley and Paliokostas 2001; Daddow and Skitmore 2004; Othman 194 2005; Dallas 2006; Hwang et al. 2014). Lin and Shen (2007); Lin et al. (2011) investigated 195 the strengths and weaknesses of the existing measurement frameworks in the context of VM 196 studies and identified 18 Key Performance Indicators for measuring VM performance. 197 Similarly, Ramly et al. (2015) identified 10 critical success factors for VM workshops 198 implementation in the Malaysian construction industry. However, the intrinsic capabilities of 199 VM to assist in the incorporation of sustainability aspects early in the briefing and design 200 stages of the project process have not been fully explored in Hong Kong practice. 
202 Research Methodology

203 Both qualitative and quantitative approaches were adopted, including a questionnaire survey

204 and three semi-structured interviews conducted with a public sector client, a VM participant

205 and a VM facilitator, respectively. The use of qualitative and quantitative approaches together

206 to study a research topic - triangulation - is a powerful to gain insights and results, to assist

207 in making inferences and in drawing conclusions (Fellow and Liu, 2015).

208

209 Questionnaire survey

210 The questionnaire was developed by comprehensive literature, discussion between the

211 research team and a pilot study with three professionals in early of 2015 . The

212 operationalisation of constructs is shown in Table 1. A cluster sampling approach was used in

213 the questionnaire survey and target survey respondents were selected based on two criteria:

214 they (i) had had working experience of sustainable construction development and VM, and

215 (ii) had attended VM workshop(s) either in the role as a facilitator, participant or client. To

216 solicit the opinions of practitioners, 323 respondents were targeted in Hong Kong. The list

217 of clients, value managers and VM participants was obtained from different sources including

218 the Institute of Value Management of Hong Kong. 73 completed survey responses were

219 received in mid of 2015 , representing a response rate of $23 \%$. Over half of the respondents

220 have been VM participants in VM workshops. 66\% of the respondents had participated in one

221 VM workshop, and that one quarter have been involved in more than five VM workshops.

222 Around $19 \%$ of the respondents were involved with school and education projects, and $12 \%$

223 were involved with offices, followed by commercial estates, hospital and transportation

224 projects. Some respondents had experienced more than one type of project and therefore 
225 chose more than one type of project for their answers. Around $97 \%$ of the respondents had 226 attended VM workshops, and 90\% reported that sustainability had been considered in the VM 227 workshops in which they were involved. However, $60 \%$ thought that sustainability was not 228 considered as a separate agenda i.e. singled out for special consideration in its own right in 229 the VM workshops, echoing interviewee responses.

\section{Insert Table 1 here}

232 The questionnaire included two sections (a sample of the questionnaire is attached in 233 Appendix A). Section I collected information related to respondent backgrounds, including 234 their involvement in VM studies, their professions, the roles they played in VM studies and 235 the types of projects they were involved in. Section II solicited respondent perceptions of 236 SWOT as a means of analysing the potential for integrating sustainability into VM. SWOT 237 analysis is a strategic planning tool used to evaluate strengths, weaknesses, opportunities and 238 threats related to a project or a business. It involves specifying the objectives and identifying 239 the internal and external factors that may affect the achievement of those objectives (Arslan 240 and Er 2008). The respondents rated their degrees of agreement against each SWOT analysis 241 factor according to a 5-point Likert scale (1= "Strongly disagree" to 5= "Strongly agree"). An 242 additional option of "Do not know" was provided to allow the respondents to express a lack 243 of understanding of the SWOT analysis factors.

\section{Semi-structured interviews}

246 Previous researchers have also conducted semi-structured interviews; for example Daddow 247 and Skitmore (2004); Abidin and Pasquire (2007); Al-Saleh and Taleb (2010), used the semi248 structured interview technique with experts in the field of VM and sustainability. Their target 249 survey respondents included construction industry practitioners (clients, project managers, 
250 contractors, consultants, property/facilities managers, end users, engineers, academics, 251 architects and quantity surveyors) working in senior-level positions. Semi-structured 252 interviews provided an interactive dialogue with a representative of each of these key 253 respondents to tap into their front-line experience using a common questionnaire.

254

255 The three interview participants in this study are key decision makers in VM workshop 256 (British Standard 2000; Kelly et al. 2003). The interviewees were selected based on their vast 257 amount of front-line experience with VM and sustainability issues and their influential roles 258 within their organizations so as to obtain a balanced picture about the integration of 259 sustainability with the VM process. All three interviewees represent "organisational elites" 260 and "key informants" and work in key and responsible positions. Interviewing "elite" 261 personnel is a common qualitative research method, which uniquely yields valuable and 262 insightful information (Marshall and Rossman 2011).

263

264 Interviewee A was the past president of the Hong Kong Institute of Value Management as 265 well as the director of a consultancy firm, having first-hand experience of organising more 266 than $50 \mathrm{VM}$ workshops worldwide. Interviewee B was the client of a public sector project 267 which won the first environmental award for greenest building in Hong Kong. Interviewee C 268 was a senior manager of a public sector organization (a fore-runner in promoting sustainable 269 development), who has participated in different VM workshops.

\section{Data analysis}

272 Data collected by questionnaire survey was analyzed using an SPSS statistical package. 273 Cronbach's alpha reliability test, Kendall's coefficient of concordance $W$ test, the descriptive 274 statistic were used to analyze the data collected; and the Mann-Whitney $U$ and Kruskal- 
275 Wallis non-parametric tests were used to check for statistically significant differences 276 between the different groups of respondents (i.e., the clients, VM facilitators and VM 277 participants). Data collected by interviews was analysed by coding and content analysis. The 278 following section presents a detailed analysis of the results.

279

280 Test of survey reliability

281 First, Cronbach's alpha was determined to measure the reliability of the data obtained 282 (Nunnally 1978; Nunnally and Bernstein 1994). Table 2 tabulates the coefficient values of 283 Cronbach's alpha for Section B' questions 8-11 (refer to attached sample survey 284 questionnaire). The coefficients range from 0.862 (Q.11) to 0.923 (Q.9). Because all of the 285 coefficients are above 0.70, the collected data are considered to be "reliable" (Nunnally 1978; 286 Nunnally and Bernstein 1994; Geroge and Mallery 2003).

287

288

[Insert Table 2 here]

289

290 Test of response consistency

291 Kendall's coefficient of concordance $W$ was used to determine the degree of association and 292 consistency of responses within the groups of questions. $W$ has possible values between 0 and $293+1$. If complete agreement between the different respondents is achieved, a significant $W$ 294 value near to +1 among all of the rank sets emerges. However, if there is no association, the 295 value of $W$ is equal to 0 (Sheskin 2011; Siegel and Castellan 1988). Hypothesis testing will 296 determine whether to accept or reject the null hypothesis.

$297 \mathrm{H}_{0}$ : there is no association between the rankings given by the respondents.

$298 \mathrm{H}_{\mathrm{A}}$ : there is an association between the rankings given by the respondents. 
300 At the $95 \%$ confidence interval, the null hypothesis $\left(\mathrm{H}_{0}\right)$ can be rejected if the value of $W$ is at 301 a low level of significance $(p<0.001)$. This rejection of the null hypothesis means that some 302 degree of consensus existed amongst the respondents when answering a particular group of 303 questions. Kendall's $W$ test is suitable when the number of elements $(\mathrm{N})$ in each group of 304 questions is at or below seven. If the number of elements in one question is more than seven, 305 the Chi-square $\left(\chi^{2}\right)$ test should be used as the best option (Siegel and Castellan 1988). Table 3 306 shows the results of applying the Chi-square test to questions 8-11, for which the respondents 307 gave rankings. The final right-hand column in Table 3 shows a rejection of the null 308 hypothesis for questions 8 and 9 (but not questions 10 and 11), indicating that there was some 309 degree of consensus among the respondents. Questions 8 and 9 were rejected because values 310 obtained using Chi-square tests were higher than the critical value of Chi-square and 311 questions 10 and 11 were accepted because the critical values were higher than the Chi312 square values obtained using SPSS.

Relative importance index

317 Sambasivan and Soon (2007) and Gündüz et al. (2013) used the relative importance index 318 (RII method) to determine the relative importance of the various variables. The same method 319 was adopted in this study. RIIs are calculated for each factor as in the following equation:

$$
\mathrm{RII}=\frac{\sum W}{(A * N)}
$$

320 where RII = relative importance index; $W=$ weighting given to each factor by respondents 321 (ranging from 1 to 5); $A=$ highest weight (i.e., 5 in this case); and $N=$ total number of 322 respondents. The RII value had a range of 0 to 1 ( 0 not inclusive); the higher the RII, the 
323 more important was the factors. The RIIs were then ranked, and the results are shown in 324 Table 4.

325

326

327

328

The Mann-Whitney $U$ and Kruskal-Wallis tests

\section{[Insert Table 4 here]}

329 A non-parametric Mann-Whitney U Test was conducted to test the hypothesis and study the 330 association of the ordinal (rank order) data with two independent sample groups (drawn from 331 the clients, VM facilitators and VM participants) that did not necessarily have equal sizes or 332 any assumed distributions (Siegel and Castellan 1988; Sheskin 2011). In a Mann-Whitney U 333 test, if the $p$-value is equal to or smaller than a predetermined significance level of $5 \%$, then 334 the two samples are considered to exhibit a statistically significant difference. However, if $p$ 335 is larger than $(\alpha=0.05)$, then the two samples are considered to exhibit no difference. $\mathrm{H}_{0}$ was 336 rejected when the significance levels for the SWOT analysis attributes were found to be equal 337 to or smaller than 0.05 . Otherwise, $\mathrm{H}_{\mathrm{A}}$ was accepted for the SWOT analysis attributes.

339 Table 5 shows significant differences at the 95\% confidence level $(\alpha<0.05)$ for the SWOT

340 attributes, including statistical differences between $8(\mathrm{~d})$ "The strategic timing of the VM

341 process enables the sustainability agenda to be highlighted at a critical decision making stage"

342 (between the client and VM facilitator and also between the VM facilitator and participants);

343 8(f) "An effective VM process allows sustainability measures to be integrated during the

344 conceptual and early design stages" (between the client and VM participants and between the

345 VM facilitator and participants); 8(g) "During VM studies, solutions are proposed that

346 promote a safe and healthy environment for the occupants (between the VM facilitator and 
347 participants); and 8(h) "Long-term proposal criteria, such as adaptability for future changes, 348 whole-life costs and select renewable resources, are considered during VM exercises 349 (between the VM facilitator and participants). Statistical differences were also found between 350 weakness attribute 9(i) "The lack of technological support for achieving sustainability 351 objectives (between the client and VM participants); opportunity attributes $10(\mathrm{~d})$ " $\mathrm{VM}$ is a 352 mechanism proved capable of delivering better sustainable value" and $10(\mathrm{~g})$ "The VM 353 process encourages participants to apply environmentally friendly technologies on site 354 (between the VM facilitator and participants); and threat attributes 11(d) "The perceived 355 additional time required for sustainable measures," 11(e) "The negative perception of green 356 buildings in terms of the additional cost involved" (between the client and VM participants 357 and between the VM facilitator and participants) and 11(i) "Ignoring the VM facilitator's 358 recommendations for achieving sustainability objectives due to the clients' limited budgets or 359 other prior commitments" (between the VM facilitator and participants). Furthermore, 360 Kruskal-Wallis $(\mathrm{K}-\mathrm{W})$ tests were conducted to determine whether other differences between 361 the respondents affected their perceptions of the relative significance of the SWOT analysis 362 attributes in integrating sustainability into the VM process (Laerd Statistics 2013). The results 363 of the K-W tests are shown in Table 6, which depicts only statistically significant different 364 items at the $95 \%$ confidence level $(p<0.05)$ for these attributes $8(d) ; 8(f) ; 10(d)$ and 11(e). 365 The K-W test is an extension of the t-test and used to compare the means of more than two 366 samples. 
371 Interview data was transcribed into field notes to prepare for analysis. Coding is the process

372 of segmenting and labeling text to form descriptions and broad themes in the data. The

373 objective of the coding process is to make sense out of text data, divide it into text segments,

374 label the segments with codes, examine codes for overlap and redundancy, and collapse these

375 codes into broad themes. The themes consist of no more than two to four words. In this study,

376 the basic steps of conducting content analysis followed the methodology introduced by

377 Fellows and Liu (2015). A qualitative content analysis was adopted. In this method, emphasis

378 is on determining the meaning of the data. Data are given coded allocations to categories and

379 groups of respondents from whom the data were obtained, so that a matrix of categorised data

380 against groups is constructed. Statements can be selected from each cell of the matrix to

381 illustrate the contents of each of the cells. As in any allocation mechanism, the categories

382 should be exclusive (i.e., data assigned to one category only) and exhaustive (i.e., categories

383 cover the research topic comprehensively).

\section{Results and discussions}

386 SWOT analysis is a tool commonly used to scan the internal strengths and weaknesses of a

387 product or service industry and highlight opportunities and threats presented by the external 388 environment (Kurttila et al. 2000; Pasonen et al. 2000; Rauch 2007). It comprises a general, 389 brief and subjective list of attributes or statements that describe the present and future trends 390 of both internal and external environments (Wickramasinghe and Takano 2009). It is also 391 considered a convenient technique for conducting situational assessments. Although SWOT 392 analysis has been conducted in various fields, only a few studies have focused on 393 sustainability and/or VM for infrastructure projects. Lu (2010) conducted a SWOT analysis 394 of construction industry strategic planning. Milosevic (2010) did also from both the investor 395 and contractor viewpoints during the planning, contracting and construction phases of a 
396 project. Other researchers have tried to quantify SWOT factors using hybrid methods. For 397 example, Kurttila et al. (2000) and Yuan (et al. 2012) used a combined SWOT-analytic 398 hierarchy process (AHP) for public housing projects. In this case, the AHP, a multi-criteria 399 decision making method for determining the relative importance of attributes within a group, 400 was used to evaluate the factors identified via SWOT analysis (Saaty 1980). However, the 401 SWOT-AHP approach is beyond the scope of this research.

402

403 In this study, strengths are represented by attributes 8(a)-(j), weaknesses by attributes 9(a)-(1), 404 opportunities by attributes $10(\mathrm{a})-(\mathrm{k})$ and threats by attributes $11(\mathrm{a})-(1)$. Table 7 shows the 405 overall mean values and RII of the SWOT attributes according to the clients, VM facilitators 406 and VM participants. Contrary to the overall mean values for weaknesses and threats, the 407 mean values for strengths and opportunities are over 3.50. The respondents might have 408 believed that integrating sustainability into the VM process presented more strengths and 409 opportunities than weaknesses and threats. A detailed discussion of the SWOT analysis of 410 integrating sustainability into the VM process is as follows:

411

412

\section{[Insert Table 7 here]}

413

414 Strengths

415 Strengths are the variables associated with an organization's strengths, variables that should 416 be taken advantage of to promote growth and development of the organization (Kangas et al. 417 2001; Yuan et al. 2012). Table 4 shows the minimum, maximum and mean scores and relative 418 ranks of various strengths. The RIIs of all of the attributes related to the strengths of 419 integrating sustainability into the VM process were above 0.6. It shows the ranking of 420 attributes from 1 to 5 (i.e., "Strongly disagree," "Disagree," "Neither agree nor disagree," 
421 "Agree" and "Strongly agree"). An additional choice of 0 representing "Do not know" was

422 provided to allow the respondents to express a lack of understanding of the SWOT attributes.

423 However, none of the respondents chose the "Do not know" option. The RII of attribute 8(c)

424 "VM provides opportunities for multidisciplinary professionals and stakeholders to become

425 involved and focus on issues relating to society and the environment" was ranked highest by

426 all respondents echoing the findings of Shen and Yu (2012). One of the interviewees stated:

427 "The Kai Tak government offices would be the first government green buildings in Hong

428 Kong. One section of the VM workshop for these government offices was allocated for the

429 brainstorming of green ideas. The Kai Tak government offices are being constructed at the

430 time of writing. Sometimes sustainability is made a key factor of the VM workshops. In one

431 education institution (the Hong Kong Polytechnic University) master plan campus expansion

432 project, a VM workshop was carried out on November 28, 2013. Many ideas were discussed

433 in this workshop, such as the recycling of food waste, whether to retain old buildings and

434 whether it was necessary to build new zero-energy buildings and minimise lifts or escalators

435 (to encourage people to use stairs and walk more to increase their health, and to save 436 electricity)."

438 It was noted in the interviews that sustainability was sometimes considered as a separate 439 agenda and integrated into other value drivers such as time, cost and quality. "Sustainability 440 issues are integral to the project functions and objectives, which should be dealt with 441 accordingly during the VM process and should not be treated as a separate agenda" (Abidin 442 and Pasquire 2005, p 178). One of the interviewees (a VM facilitator) noted the following: 443 "In a recent VM workshop focusing on accessibility for the disabled on pedestrian 444 footbridges, we evaluated the energy effectiveness of the air conditioning systems installed in 445 the footbridges. During our 'option analysis,' we evaluated how to take out the air 
446 conditioning system while also improving the indoor air quality and lift ventilation. We

447 looked at the options of installing solar panels on the lifts. The aim of this workshop was to 448 make the pedestrian lifts more energy efficient (reducing energy consumption) and make 449 them comfortable for pedestrians. That whole VM workshop was focused purely on energy 450 reduction itself, so sustainability considerations were clearly a separate agenda in this case 451 but VM workshops or can alternatively be integrated into other value-enhancing objectives."

453 The attribute 8(i) "Stakeholders are strongly encouraged to propose sustainable solutions at 454 an early stage" and 8(f) "An effective VM process allows sustainability measures to be 455 integrated during the conceptual and early design stage" were ranked second and third. VM 456 ensures that sustainability issues should be brought to the attention of all stakeholders before 457 critical decisions are made (Abidin and Pasquire 2005). The VM facilitator interviewed noted 458 that the VM process should start as early as the feasibility or inception stages: "In a recent 459 (education institution) project related to master planning, the VM workshop was conducted at 460 a very early stage. In the information phase, many green ideas were incorporated into the 461 early design stage. In terms of a functional diagram, the key building functions received by 462 the client were included in this phase. Sustainability of the building could itself be a key 463 function. The functional analysis, brainstorming (creativity), evaluation and implementation 464 phases are the most common phases adopted in most VM workshops. The ideas generated at 465 this point become part of the project brief. Recently sustainability has become included in the 466 design and development stage of most projects. The first question to be asked is whether the 467 existing facilities should be redeveloped or rebuilt. If the services can be provided without 468 rebuilding or demolishing the facilities, how the sustainability objectives can be attained 469 should be looked at. He further elaborated that during the decision making process, the client 470 can determine whether a new building is necessary or whether the refurbishment or extension 
471 of any existing facility can fulfill the client's requirements. In addition, during the VM

472 workshop, the participants were asked to write down the functions of the buildings for the 473 next 50 years. One participant left a blank sheet because during the next 50 years, he felt, no

474 more education institutions would be needed because education may be provided in virtual 475 environments. Management later shortened the planning horizon to 10 years to make it more 476 practical.

478 Shen and Yu (2012) suggested that VM workshops provide diverse knowledge sources for 479 sustainable development. They further pointed out that a sustainability vision should be 480 discussed as early as possible in the design and briefing stages of a project. Sustainability 481 should be integrated into all of the activities involved in the project design and development 482 processes, with close interactions between the clients and key stakeholders. Attribute 8(g) 483 "During the VM studies, solutions are proposed that promote a safe and healthy environment 484 for the occupants" was ranked last.

Weaknesses

487 The weaknesses are the variables that may impede or question the need for growth and 488 development of an organisation (Kangas et al. 2001; Yuan et al. 2012). Table 4 shows the 489 minimum, maximum and mean scores and relative ranks of the weaknesses. The RIIs of 490 weaknesses of integrating sustainability into the VM process range from 0.548 to 0.674 . 491 Attribute 9(c) "The lack of well-trained staff and expertise of the VM participants in relation 492 to sustainable development" was ranked first, a finding echoed by the interviewees' remarks 493 that Hong Kong lacked well-trained staff and that VM participants may be unaware of 494 sustainability issues. Attribute 9(d) "The lack of client supports in achieving sustainable 495 construction during the VM exercise" was ranked second. However, one interviewee asserted 
496 that clients were "willing to achieve sustainability objectives. In some instances, it's the users 497 who may not be interested in or willing to achieve sustainability objectives. There are many 498 user groups in the Kai Tak government offices. The designer suggested sensor lighting 499 instead of traditional lighting to save energy, but the user groups objected to the idea. There 500 was an option for a bicycle park instead of a car park. The user groups were not happy with 501 this idea and deleted this sustainability option." The Hong Kong property market also, is not 502 mature in terms of sustainability and lacks awareness and understanding of the basic 503 principles of sustainability (Chen 2013), as well as passive and negative perceptions about 504 integration (Abidin and Pasquire 2005). Attributes 9(i) “The lack of technological support for 505 achieving sustainability objectives" was ranked last among the weaknesses.

506

507 In Hong Kong, some private sector interests invest in sustainable buildings as part of their 508 corporate social responsibility. According to one of the interviewees, "currently there is social 509 pressure on the private sector that stimulates clients to consider sustainable buildings. 510 Private-sector organizations such as the Hong Kong Jockey Club wants to be seen as good 511 members of society, so they want to establish themselves as socially responsible organisations. 512 In the short run, all of these sustainability considerations cost more. They are not cost513 reduction measures, and tend to cost more at the initial design and development stages." He 514 further continued, "in the long run, taking account of life-cycle costs, will benefit the 515 occupants and future generations. Most of these organisations are targeting LEED and BEAM 516 platinum or gold certification. The Hong Kong Jockey Club's Sha Tin Communications and 517 Technology Centre will be a very environmentally friendly building. This Jockey Club 518 project is targeting gold LEED or BEAM assessment certificates." However, some of the 519 Hong Kong developers who maximise profit from every square foot rarely care about 520 investing in sustainable buildings. The private-sector developers merely try to meet the 
521 minimum environmental requirements. According to one associate dean of architecture,

522 passive design that takes account of factors such as the orientation of a building in relation to

523 sun and wind patterns and to window-to-wall ratios is crucial. If the design maximises natural

524 lighting and ventilation, considerable energy savings may result without spending a cent on

525 advanced technologies. However, the dean also stressed that the buildings on Hong Kong

526 Island face north to secure harbor views at the expense of natural light (Chen 2013).

527

528 Opportunities

529 Opportunities are those variables an organisation can take advantage of to ensure its future 530 growth and development (Kangas et al. 2001; Yuan et al. 2012). Table 4 shows the minimum,

531 maximum and mean scores and relative ranks of opportunities of integrating sustainability

532 into the VM process. The RIIs of opportunities for integrating sustainability into the VM

533 process were 0.7. Attributes 10(f) "Encouraging the reduction, reuse and recycling of

534 construction and demolition waste" and $10(\mathrm{~g})$ "The VM process encourages participants to

535 apply environmentally friendly technologies on site" were top ranked opportunities of

536 integrating sustainability into the VM process. SAVE International (2007) suggests that VM

537 is a mechanism proved capable of delivering better sustainable value to a project. Similarly,

538 Abidin and Pasquire (2005) recommend producing tools, guidelines, improving knowledge

539 for sustainable integration into the VM process. Promoting the integration of sustainability

540 into the VM process will enhance the reputation of $\mathrm{VM}$ as a value enhancing technique and

541 enable it to remain competitive in delivering its services. Furthermore, Shen and Tam (2002)

542 suggest that including sustainability into the VM process will highlight the financial and non-

543 financial incentives of sustainable development to clients and contractors during VM studies.

544 It is necessary that by including sustainability issues the clients and contractors will benefit in

545 monetary and non-monetary terms. Attribute 10(e) "The legal enforcement of environmental 
546 protection and the implementation of sustainable practices" was ranked the last opportunity 547 attribute.

548

549 Threats

550 Threats are the variables that may affect or prevent the growth of an organisation (Kangas et 551 al. 2001; Yuan et al. 2012). Table 4 shows the minimum, maximum and mean scores and 552 relative ranks of threats. The RIIs of threats to the process of integrating sustainability into 553 the VM process range from 0.586 to 0.718 . The majority of the RIIs are greater than 0.6. 554 Attributes 11(d) "The perceived additional time required for sustainable measures"; 11(b) 555 "The client and service provider react passively in fulfilling environmental and social needs", 556 and 11(e) "The negative perception of green buildings in terms of the additional cost involved" 557 ranked first $(\mathrm{RII}=0.718)$, second $(\mathrm{RII}=0.715)$ and third $(\mathrm{RII}=0.677)$ respectively as major 558 threats to the integration of sustainability issues into the VM process. Abidin and Pasquire $559(2005 ; 2007)$ identified the time limitation as a practical barrier to the integration of 560 sustainability into the VM process. Hence, it is impractical and difficult to address all 561 sustainability issues within a VM workshop. There could also be other potential barriers 562 including perceived extra costs of the integration of sustainability into the VM process. Since, 563 the initial cost of a sustainable building may be 2 to 7 percent higher than the cost of an 564 ordinary building and with a long payback period. As revealed in the interview, Sing Yin 565 Secondary School project has more than double the normal payback period. Furthermore, 566 Williams and Dair (2007); Pitt et al. (2009) and Häkkinen and Belloni (2011) identified 567 different barriers including lack of client demand, awareness and the affordability of 568 sustainable buildings. Meryman and Silman (2004) point out that cost as an important barrier 569 to the implementation of green specifications. The study by Ofori and Kien (2004) in 570 Singapore also found that the perception of extra cost is a fundamental obstacle to the design 
571 team in persuading the clients and other relevant stakeholders to include environmental

572 considerations into the design and construction processes. Extra costs also relate to time, and 573 any delay in workflow caused by green practice would have economic implications. Similarly, 574 Sayce et al. (2007); Sodagar and Fieldson (2008) and Lam et al. (2009) identified "perceived 575 additional cost" as one of the main obstacles to the implementation of sustainable building 576 design in construction projects. Attribute 11(h) "The VM facilitator's fear of the extra 577 responsibilities involved in highlighting the importance of sustainable development" ranked 578 the lowest potential threat to inclusion in VM workshops.

579

\section{0 | Implications}

581 This research study has highlighted some important practical implications for clients, 582 contractors and VM practitioners. The study demonstrated that the current practices are 583 generally neglecting integration of sustainability into the VM process due to cost and time 584 constraints. There are ample strengths and opportunities recommended by this study for 585 integrating sustainability into the VM process which are beneficial for the clients and 586 contractors for achieving value for money and meeting sustainability targets.

\section{Limitations and future studies}

589 The major limitation of this study is that the completed survey and interviewees were held in 590 only the one location, i.e., Hong Kong. The results may not able be generalisable to other 591 well-developed countries but only to other locations with similar sustainability and VM 592 practicing environments. Therefore, further research should be conducted at other locations 593 and compared with the findings of this SWOT analysis. Moreover, in future research a hybrid 594 SWOT-AHP decision-making method could be applied to a larger sample to make pair-wise 595 comparison between the identified SWOT attributes. 


\section{Conclusions}

598 This research study is presented as a contribution to understanding the factors affecting the 599 integration of sustainability into the VM process. The study has identified areas of strengths, 600 which support the notion of integrating sustainability into the VM process, and weaknesses, 601 which could be converted into opportunities and threats to be avoided. The results indicate 602 that the strongest factors (strengths and opportunities) relate to the potential for VM exercises 603 to provide for multidisciplinary professionals and stakeholders involvement, and a focus on 604 issues relating to society and a sustainable built environment at the conceptual and design 605 stages of a project to encourage the reduction, reuse and recycling of construction and 606 demolition waste. However, it is recognised that the client needs to strike a balance between 607 economic, social and environmental objectives. The strongest factors (weaknesses and threats) 608 hindering the potential for sustainability integration into the VM process are the lack of well609 trained staff and low levels of VM participant expertise in relation to sustainable 610 development and the additional time and resources required to achieve sustainability targets.

611 The perception of extra time and cost was seen as the main obstacle to the implementation of 612 sustainability initiatives. All interviewees observed that sustainability has recently been 613 considered an important issue for both public and private sector projects in Hong Kong, but 614 especially the former. All interviewees agreed that design teams should incorporate 615 sustainability objectives early in the project design and development stages, and that design 616 solutions should not conflict with sustainability and environmental objectives. Both public 617 and private sector clients understand the concept of sustainability and are willing to 618 implement them through the VM process. Along with other value drivers, sustainability 619 should be given priority and should be integrated in the early stages of the VM process for 620 successful project delivery. 
621

622 Under the conceptual framework outlines earlier, VM practitioners should incorporate 623 sustainability consideration into VM workshops. The existing target of value creation and 624 enhancement should be expanded to cover environmental improvement and more specifically 625 climate mitigation. Thus, managers may instil better value of money for their projects. On the 626 research front, suitable tools need to be developed to evaluate managers to achieve the above 627 integration with competence and objectivity. SWOT analysis is one such tool.

628

629

630 
631

632

633

634

635

636

637

638

639

640

641

642

643

644

645

646

647

648

649

650

651

652

653

654

655

656

657

658

659

660

661

662

663

664

665

\section{References}

Aarseth, W., Ahola, T., Aaltonen, K., Økland, A. and Andersen, B. (2016), "Project sustainability strategies: A systematic literature review," International Journal of Project Management, available online on 23 December 2016.

Abidin, N.Z. and Pasquire, C.L. (2003), "Moving towards sustainability through value management," Proceedings of the Joint International Symposium of CIB Working Commissions W55 and W107, (2) 258-268, Singapore.

Abidin, N.Z. (2005), Using value management to improve the consideration of sustainability within construction, Doctor of Philosophy, Loughborough University, UK.

Abidin, N.Z. and Pasquire, C.L. (2005), "Delivering sustainability through value management: concepts and performance overview," Construction and Architectural Management, 12(2) 168-180.

Abidin, N.Z. and Said, I. (2006), "Involvement of sustainability issues in value management: requisite factors," International Conference of Construction Industry, Padang, Indonesia, 12-24 June 2006.

Abidin, N.Z. and Pasquire, C.L. (2007), "Revolutionize value management: a mode towards sustainability," International Journal of Project Management, 25(3) 275-282.

Al-Saleh, Y.M. and Taleb, H.M. (2010), "The integration of sustainability within value management practices: a study of experienced value managers in the GCC countries," Project Management Journal, 41(2) 50-59.

Alexandre, J., Henbriques, J., Catarino, J., Nogueira, A., Rodrigues, F. and Camocho, D. (2006), "How to measure value from a sustainable point of view," International Conference of the Institute of Value Management, Brighton, UK.

Architectural Services Department (2011), Task Force on Kai Tak Harbour Front Development: Kwun Tong Promenade Stage 2. (http://goo.g1/7u2XC1) (October 10, 2014).

Arslan, O. and Er, I.D. (2008), "A SWOT analysis for successful bridge team organization and safer marine operations," Process Safety Progress, 27(1) 21-28.

AS/NZS 4183 (1994), Australian/New Zealand Standard, Value Management, Joint Technical Committee, OB/6, April.

Barton, R., Jones, D. and Anderson, H. (1999), "Incorporating the values of ecologically sustainable development into project definitions using soft value management," International Conference of the Institute of Value Management, Hong Kong.

Better Buildings Summit (2003), "Better Buildings Summit Issues Paper," Department of Trade and Industry, HMSO, London, https://goo.gl/TvRa9D (Nov. 04, 2017). 
666 BRE Scotland (2001), Report on Value Management Workshops for Community Self Build 667 Scotland, BRE Scotland. (http://goo.gl/rHv5WB) (Dec. 10, 2013).

668 British Standard (2000), BS EN 12973 Value Management, https://bsonline.techindex.co.uk. 669 (May 03, 2014)

670

Brundtland, G.H. (1987), Our Common Future: The World Commission on Environment and 671 Development, Oxford University Press, Oxford.

672

673

674

Buildings Performance Institute Europe (2011), Final Draft: Principles for Nearly ZeroEnergy Buildings - Paving the Way for Effective Implementation of Policy Requirements, Buildings Performance Institute Europe, Brussels.

675

676

677

Carvalho, M.M. and Rabechini, R. (2017), "Can Project sustainability management impact project success? An empirical study applying a contingent approach," International Journal of Project Management, available online on 14 March 2017.

678

679

680

Chen, A. (2013), Take a Look Inside Sing Yin Secondary School, One of the World's Greenest, Thursday, 14 November 2013, South China Morning Post. (http://goo.gl/yFNL5v) (Aug. 06, 2014).

681

682

683

Council for Sustainable Development (2011), Combat Climate Change: Energy Saving and Carbon Emission Reduction in Buildings, Hong Kong SAR, China. (http://goo.gl/ZjpGw8) (Aug. 06, 2014).

684

685

686

Daddow, T. and Skitmore, M. (2004), "Value management in practice: an interview survey," Australasian Journal of Construction Economics and Building, 4(2) 11-18 (http://goo.gl/KR7vjp).

687

688

Dallas, M. (2006), Value and risk management: A guide to best practice, Blackwell Publishing, Oxford.

689

690

Fellows, R. and Liu, A. (2015), Research Methods for Construction, 4th edn., Wiley Blackwell, Oxford.

691

692

Fewing, P. (2005), Construction Project Management: An Integrated Approach, Taylor \& Francis, Oxon.

693

694

Fong, S.W. (2003), "Value management - going all out for knowledge creation," The Value Manager, 9(1) available at (http://goo.gl/IEXlQo) (Aug 20, 2015).

695

Geroge, D. and Mallery, P. (2003), SPSS for Windows Step by Step: A Simple Guide and 696 Reference. 11.0 Update, 4th edn., Allyn and Bacon, Boston.

697 Gündüz, M., Nielsen, Y. and Özdemir, M. (2013), "Quantification of Delay Factors Using the 698 Relative Importance Index Method for Construction Projects in Turkey," Journal of 699 Management in Engineering, 29(2), 133-139.

700 Häkkinen, T. and Belloni, K. (2011), "Barriers and drivers for sustainable building," Building $701 \quad$ Research \& Information, 39(3), 239-255. 
702

703

704

705

706

707

708

709

710

711

712

713

714

715

716

717

718

719

720

721

722

723

724

725

726

727

728

729

730

731

732

733

734

735

736

737

738

739
Hill, R.C. and Bowen, P.A. (1997), "Sustainable construction: principles and a framework for attainment," Construction Management and Economics, 15(3) 223-239.

Hiley, A. and Paliokostas, P.P. (2001), "Value management and risk management: An examination of the potential for their integration and acceptance as a combined management tool in the U.K construction," Construction Industry Proceedings of COBRA 2001, Royal Institution of Chartered Surveyors, London, U.K. (https://goo.gl/Reb2oT) (Jan 9, 2015).

HM Treasury (1996), Central Unit on Procurement Guidance No. 54 Value Management, The Stationary Office. (http://goo.gl/TKpc5L) (July 04, 2014).

Ho, S.K. and Au, W.Y.V. (2010), "Optimizing the environmental performance of government buildings and facilities," The Sixteenth Annual International Sustainable Development Research Conference, 30 May-1 June, 2010 The Kadoorie Institute, Hong Kong. (http://goo.gl/Bt8dPT) (Jan. 09, 2014).

Hwang, B., Zhao, X. and Ong, S. (2014), "Value management in Singaporean building projects: implementation status, critical success factors, and risk factors," Journal of Management in Engineering, 04014094.

Kangas, J., Pesonen, M., Kurttila, M. and Kajanus, M. (2001), "Integrating AHP with SWOT analysis," Proceedings of the Sixth Int. Symposium on the Analytic Hierarchy Process, Institute for Accounting and Controlling, p. 189-198, University of Berne, Berne, Switzerland.

Kelly, J. and Duerk, D. (2002), "Construction Project Briefing/Architectural Programming," Best Value in Construction, eds. J. Kelly, R. Morledge and S. Wilkinson,) 38-58, Blackwell Science Ltd.

Kelly, J., Hunter, K. and Male, S. (2003), "The client's value system explored: case studies from the UK public sector," In Proceedings of the joint International Symposium of CIB Working Commissions W55, W65 and W107, Knowledge in Construction 1, Singapore, October 22-24, 2003, 423-433.

Kelly, J., Male, S. and Graham, D. (2004), Value Management of Construction Projects, Wiley-Blackwell Science Ltd., Oxford.

Kibert, C.J. (1994), "Final Session," First International Conference of CIB TG 16 on Sustainable Construction, 6-9 November 1994. Tampa, FL.

Kirk, S.J. and Spreckelmeyer, K.F. (1988), Creative Design Decisions, Van Nostrand Reinhold Company, New York.

Kurttila, M., Pesonen, J., Kangas, M. and Kajanus, M. (2000), "Utilizing the analytic hierarchy process (AHP) in SWOT analysis: a hybrid method and its application to a forest-certification case," Forest Policy and Economics, (1) 41-52.

Laerd Statistics (2013), Kruskal-Wallis H Test using SPSS Statistics. (http://goo.gl/TTdjC9) (on September 29, 2014. Lund Research Ltd. 
740

750

751

752

753

754

755

756

757

758

759

760

761

762

763

764

765

766

767

768

769

770

771

772

773

774

Lam, P.T.I. (1995), "Applications of value engineering in the construction industry," The Asia Pacific Building and Construction Management Journal, (1) 18-24.

Lam, P.T.I., Chan, E.H.W., Chau, C.K., Poon, C.S. and Chun, K.P. (2009), "Integrating Green Specifications in Construction and Overcoming Barriers in their Use," Journal of Professional Issues in Engineering Education and Practice, 135(4), 142-152.

Langston, C.A. and Ding, G.K. (2001), Sustainable Practices in the Built Environment, 2nd edn., Butterworth-Heinemann, Oxford.

Lin, G., Shen, G., Sun, M. and Kelly, J. (2011), "Identification of key performance indicators for measuring the performance of value management studies in construction," Journal of Construction Engineering and Management, 137(9), 698-706.

Lin, G. and Shen, Q. (2007), "Measuring the performance of value management studies in construction: Critical Review," Journal of Management in Engineering, 23(1), 2-9.

Lu, W. (2010), "Improved SWOT Approach for conducting strategic planning in the construction industry," Journal of Construction Engineering and Management, 136(12) 1317-1328.

Male, S., Kelly, J., Fernie, S., Grönqvist, M. and Bowles, G. (1998), The Value Management Benchmark: A Good Practice Framework for Clients and Practitioners, Thomas Telford Publishing, London.

Marcelino-Sádaba, S., González-Jaen, L.F. and Pérez-Ezcurdia, A. (2015), "Using project management as a way to sustainability. From a comprehensive review to a framework definition," Journal of Cleaner Production, 99, 1-16.

Marshall, C. and Rossman, G.B. (2011), Designing qualitative research, 4th edn, SAGE Publications, Inc., California.

Martens, M.L. and Carvalho, M.M. (2016), "Key factors of sustainability in project management context: A survey exploring the project managers' perspective," International Journal of Project Management, available online on 14 May 2016.

Meryman, H. and Silman, R. (2004), "Sustainable engineering-Using specifications to make it happen," Structural Engineering International (IABSE, Zurich, Switzerland), 14(3), 216-219.

Milosevic, I. (2010), "Practical application of SWOT analysis in the management of a construction project," Leadership and Management in Engineering, 10(2) 78-86.

Myers, D. (2013), Construction Economics: A New Approach, 3rd edn., Routledge, Oxon.

Norton, B.R. and McElligott, W.C. (1995), Value Management in Construction, Macmillan Press, London.

Nunnally, J.C. (1978), Psychometric Theory, 2nd edn., McGraw-Hill, New York. 
775 Nunnally, J.C. and Bernstein, I.H. (1994), Psychometric Theory, McGraw-Hill, Sydney.

776 Ofori, G. and Kien, H.L. (2004), "Translating Singapore architects' environmental awareness 777 into decision making," Building Research \& Information, 32, (1), 27-37.

778 Oke, A. E., and Aigbavboa, C. O. (2017), "Sustainable Value Management for Construction 779 Projects," Springer.

780

781

782

Oke, A.E., Aghimen, D.O. and Olatunji, S.O. (2015), "Implementation of Value Management as an economic sustainability tool for building construction in Nigeria," International Journal of Managing Value and Supply Chains, 6(4), December, 55-64.

783

784

Organisation for Economic Co-operation and Development (2010), "Regulatory Policy and the Road to Sustainable Growth," https://goo.gl/UWQvPH (Nov. 30, 2017).

785

786

Othman, A.A. (2005), "Value and risk management protocol for dynamic brief development in construction," Emirates Journal Engineering Research, 10(2), 23-26.

787

788

789

790

791

792

793

794

795

796

797

798

799

Parker, D.E. (1998), Value Engineering Theory, The Lawrence D. Miles Value Foundation, Washington, DC.

Pasonen, M., Kurttila, M., Kangas, J., Kajanus, M. and Heinonen, P. (2000), “Assessing the priorities using A'WOT among resource management strategies at the Finnish forest and park service," Forest Science, 47(4) 534-541.

Pitt, M., Tucker, M., Riley, M. and Longden, J. (2009), "Towards sustainable construction: promotion and best practices," Construction Innovation, 9, 201-224.

Ramly, M.Z., Shen, G. and Yu, A. (2015), "Critical success factors for value management workshops in Malaysia," Journal of Management in Engineering, 31(2), 05014015-7.

Rauch, P. (2007), "SWOT analyses and SWOT strategy formulation for forest owner cooperations in Austria," European Journal for Forest Research, 126(3) 413-420.

Saaty, T.L. (1980), The Analytic Hierarchy Process: Planning, Priority Setting, Resource Allocation, McGraw-Hill, New York.

800 Sambasivan, M., and Soon, Y. W. (2007). "Causes and effects of delays in Malaysian 801 construction industry," International Journal of Project Management, 25(5),517-526.

802

803

SAVE International (2007), Value Standard and Body of Knowledge. (http://goo.gl/ob9C8r) (July 23, 2014).

804 Sayce, S., Ellison, L. and Parnell, P. (2007), "Understanding investment drivers for UK 805

Schneider, M. (1999), "Value management and sustainability: an opportunity to revolutionize the construction industry," Managing Sustainable Values, Proceedings of the International Conference of the Institute of Value Management Hong Kong, 6-7 May, 1999. 
809

810

811

812

813

814

815

816

817

818

819

820

821

822

823

824

825

826

827

828

829

830

831

832

833

834

835

836

837

838

839

840

841

842

843
Shen, G. Q., Yu, A. T., and Chung, J. K. (2015), "6 VM Applications," Value Management in Construction and Real Estate: Methodology and Applications, 66.

Shen, G.Q. and Yu, A.T.W. (2012), "Value management: recent developments and way forward," Construction Innovation: Information, Process, Management, 12(3) 264-271.

Shen, L.Y. and Tam, V.W.Y. (2002), "Implementation of environmental management in the Hong Kong construction industry," International Journal of Project Management, 20(7) 535-543.

Shen, Q.P. (1993), A Knowledge-Based Structure for Implementing Value Management in the Design of Office Buildings, PhD thesis, University of Selford, British Library, Document Supply Centre, UK.

Shen, Q.P., Brandon, P. and Baldwin, A. (2009), Collaborative Construction Information Management, Spon Press, Oxon.

Sheskin, D.J. (2011), Handbook of Parametric and Nonparametric Statistical Procedures, 5th edn., Chapman and Hall/CRC.

Siegel, S. and Castellan, N.J. (1988), Nonparametric Statistics for the Behavioral Sciences, 2nd edn., McGraw-Hill, New York.

Sodagar, B. and Fieldson, R. (2008), "Towards a sustainable construction practice," Construction Information Quarterly, 10, 101-108.

Standards Australia (2007), Australian Standards: Value Management, Standards Australia, Sydney.

Stephenson, M. (2003), How Can Value Engineering be used to Enhance the Sustainability of Major Engineering Developments? MSc Dissertation, University of Strathclyde, United Kingdom.

Tahir, M. Z., Nawi, M. N. M., and Ibrahim, A. (2016), "Value Management (VM): A Strategic Approach for Improving Energy Efficiency," International Journal of Supply Chain Management, 5(4).

Thiry, M. (1997), Value Management Practice, Project Management Institute, Newtown Square, PA.

U.S. Department of Energy (2008), Energy Efficiency Trends in Residential and Commercial Buildings, U.S. Department of Energy's Office of Energy Efficiency and Renewable Energy, U.S.A.

UNEP (2009), Building and Climate Change: Summary for Decision-Makers, United Nations Environment Programme, Paris.

Wickramasinghe, V. and Takano, S. (2009), "Application of combined SWOT and analytic hierarchy process (AHP) for tourism revival strategic marketing planning: a case of Sri 
844 845

846

847

848

849

850

851

852

853

854

855

856

857

858

859

860

861

862

863

864

865

866

867

868

869

870

871

872

873

874

875

876

877

878

879

Lanka tourism," Journal of the Eastern Asia Society for Transportation Studies, (8) 954969.

Williams, K. and Dair, C. (2007), "What is Stopping Sustainable Building in England? Barriers Experienced by Stakeholders in Delivering Sustainable Developments," Sustainable Development, 15, 135-147.

Wolstenholme, A. (2009), Never Waste a Good Crisis: A Review of Progress since Rethinking Construction and Thoughts for Our Future, Construction Excellence, London.

Works Bureau (2002), Technical Circular No. 35/2002, Environment, Transport and Works Bureau Technical Circular, Implementation of Value Management in Public Works Projects, Environment, Transport and Works Bureau, Hong Kong SAR, China.

Yao, R. (2013), Design and Management of Sustainable Built Environments, Springer, London.

Yates, A. (2003), "Sustainable buildings: benefits for constructors," Building Research Establishment London.

Yeomans, P. (2002), "Environmentally sustainable development plus value management equals results minus rhetoric," International Conference of the Institute of Value Management Hobart, Australia.

Yip, C.H. and Ho, W.Y. (2013), "Enhancing building energy efficiency - a concerted effort of the trade and the government," Proceedings of 4th Greater Pearl River Delta Conference on Building Operation and Maintenance - Sustainable Operation and Maintenance for Green Buildings, 12 December 2013. (http://goo.gl/cDhJ2d) 103-107, EMSD, Hong Kong SAR, China.

Yu, A.T.W. (2007), "A Value Management Framework for Systematic Identification and Precise Representation of Client Requirements in the Briefing Process," Doctor of Philosophy, The Hong Kong Polytechnic University, Hong Kong SAR, China.

Yu, A.T.W., Shen, Q.P. and Chan, E.H.W. (2005a), "An analytical review of the briefing practice in Hong Kong's construction industry," The International Journal of Construction Management, 5(1) 77-89.

Yu, A.T.W., Shen, Q.P., Kelly, J. and Hunter, K. (2005b), “Application of value management in project briefing," Facilities, 23(7/8) 331-342.

Yu, A.T.W., Shen, Q.P., Kelly, J. and Hunter, K. (2006a), "An investigation of the critical success factors in construction project briefing by way of content analysis," Journal of Construction Engineering and Management, ASCE, 132(11) 1178-1186.

Yu, A.T.W., Shen, Q.P., Kelly, J. and Hunter, K. (2007), "An empirical study of the variables affecting construction project briefing/architectural programming," International Journal of Project Management, 25(1) 198-212. 
880 Yu, A.T.W., Shen, Q.P., Kelly, J. and Hunter, K. (2008), "A comparative study of the 881 variables in construction project/architectural programming," Journal of Construction 882 Engineering and Management, 134(2) 122-138.

883 Yu, A.T.W., Shen, Q.P., Kelly, J. and Lin, G.B. (2006b), "A value management approach to 884 strategic briefing: an exploratory study," International Journal of Architectural 885 Engineering and Design Management, 2(4) 245-259.

886 Yuan, J., Guang, M., Wang, X., Li, Q. and Skibniewski, M. (2012), "Quantitative SWOT 887 analysis of public housing delivery by Public-Private Partnerships in China based on the 888 perspective of the public sector," Journal of Management in Engineering, 28(4) 407-420. 
Department of Building and Real Estate, The Hong Kong Polytechnic University Project entitled "SWOT analysis of integrating sustainability into the value management process for construction projects"

\section{About the Respondent (Only overall statistical data will be compiled, i.e., individuals not identifiable)}

1. Have you ever been involved in value management (VM) workshop(s) (to-date)?

$\square$ Yes $\square$ No (Please pass a blank copy to someone whom you know with such experience)

2. If yes, how many VM workshops have you ever been involved with?
$\square 1$
$\square 2$
$\square 3 \quad \square 4$
$\square 5 \quad \square$ more than 5

3. Your general role:
$\square$ Client/Project Manager $\square$ Contractor $\square$ Sub-contractor
$\square$ Property/Facilities Manager
$\square$ End User $\square$ Engineer $\square$ Environmental Expert $\square$ Academic $\square$ Architect $\square$ Quantity Surveyor
$\square$ Other pls. specify:

4. Your role in VM exercise(s)?
$\square$ Client
$\square$ VM Facilitator
VM participants or team member

5. Is sustainability considered in VM workshops which you were involved with?

$\square$ Yes $\square$ No

6. Is sustainability regarded as a separate agenda in VM workshop(s)?

$\square$ Yes $\square$ No

7. Which of the following types of projects have you been involved with? (More than one box may be selected)

$\square$ Commercial Estate $\square$ Offices $\square$ Entertainment and Exhibition Centre

$\square$ Hospital $\quad \square$ Transportation $\quad \square$ Water Supply \& Treatment $\square$ Power \& Energy

$\square$ ICT (Information \& Communication Tech) $\square$ Housing Estate $\quad \square$ Police \& Prison

$\square$ School \& Education $\square$ Waste Management (Landfill) $\square$ Others (please specify)

Please rate the following statements based on a scale from $0-5$, where " 0 " represents "Do not know", " 1 " "Strongly disagree", “ 3 " "Neither agree nor disagree "and " 5 " represents "Strongly agree".

\section{SWOT Analysis of Sustainability integration into Value Management}

\begin{tabular}{|l|l|l|l|l|l|l|l|}
\hline $\begin{array}{l}\text { 8. Please rate the following statements regarding the relative frequency } \\
\text { of the following strengths of Sustainability integrating into VM }\end{array}$ & $\mathbf{0}$ & $\mathbf{1}$ & $\mathbf{2}$ & $\mathbf{3}$ & $\mathbf{4}$ & $\mathbf{5}$ \\
\hline $\begin{array}{l}\text { a) VM workshops recommend solutions for energy and resource efficient } \\
\text { buildings }\end{array}$ & $\square$ & $\square$ & $\square$ & $\square$ & $\square$ \\
\hline $\begin{array}{l}\text { b) VM workshops provide diverse knowledge sources for sustainable } \\
\text { development }\end{array}$ & $\square$ & $\square$ & $\square$ & $\square$ & $\square$ \\
\hline $\begin{array}{l}\text { c) VM provides opportunities for multi-disciplinary professionals and } \\
\text { stakeholders' involvement to focus on issues relating to society and } \\
\text { environment }\end{array}$ & $\square$ & $\square$ & $\square$ & $\square$ \\
\hline $\begin{array}{l}\text { d) Strategic timing of VM process enables sustainability agenda to be } \\
\text { highlighted at a critical decision making stage }\end{array}$ & $\square$ & $\square$ & $\square$ & $\square$ & $\square$ \\
\hline e) VM promotes sustainable design for a project & $\square$ & $\square$ & $\square$ & $\square$ & $\square$ & $\square$ \\
\hline f) Effective VM process allows integration of sustainability measures during & $\square$ & $\square$ & $\square$ & $\square$ & $\square$ \\
\hline
\end{tabular}

Pls. return by email, fax or mail. 
the conceptual and early design stage

g) During VM studies, solutions are proposed which promote safe and healthy environment for occupants

h) Consider long-term criteria in proposals i.e. adaptability for future changes, whole-life costs, select renewable resources etc. during VM exercises

i) Encourage strong participation of stakeholders for proposing sustainable solutions at a very early stage

j) Recommend optimum utilisation of natural resources

k) Others, pls. specify:

\section{Please rate the relative frequency of the following weaknesses of} Sustainability integrating into VM

a) Lack of government legal enforcement of sustainability policies

b) Additional management and operational cost of project for sustainability measures

c) Lack of well trained staff and expertise of VM participants about sustainable development

d) Lack of client's support in achieving sustainable construction during VM exercise

e) Lack of contractors, sub-contractors and suppliers' cooperation for achieving sustainability goals

f) Lack of incentives for clients/contractors for achieving sustainable development goals

g) Unclear project brief, poor specifications or inadequate business cases for achieving sustainable development

h) Difficult to enforce environmental performance

i) Lack of technological support for achieving sustainability objectives

j) Lack of integration of sustainability into VM studies

k) Lack of sustainable construction guidance

1) Not highlighting corporate social responsibility for achieving environmental and sustainable needs of society during VM process

m) Others, pls. specify:

\section{Please rate the relative frequency of the following opportunities of} Sustainability integrating into VM

a) Inclusion of sustainability issues early in the VM practices

b) Introduce sustainability guidance for VM practitioners

c) Promote client's interest on sustainability as a primary value driver

d) Prove VM capability as a mechanism to deliver better sustainable value

e) Legal enforcement on environmental protection and implementation of sustainable practices

f) Encourage reduction, reuse and recycling of construction and demolition waste

g) Encourage to apply environmentally friendly technologies on site

h) Provide in-house training on environmental management

i) Establish waste management plan during VM exercise

j) Inclusion of environmental scoring in tender process

k) Highlight financial and non-financial incentives of sustainable development for clients and contractors during VM studies

1) Others, pls. specify:

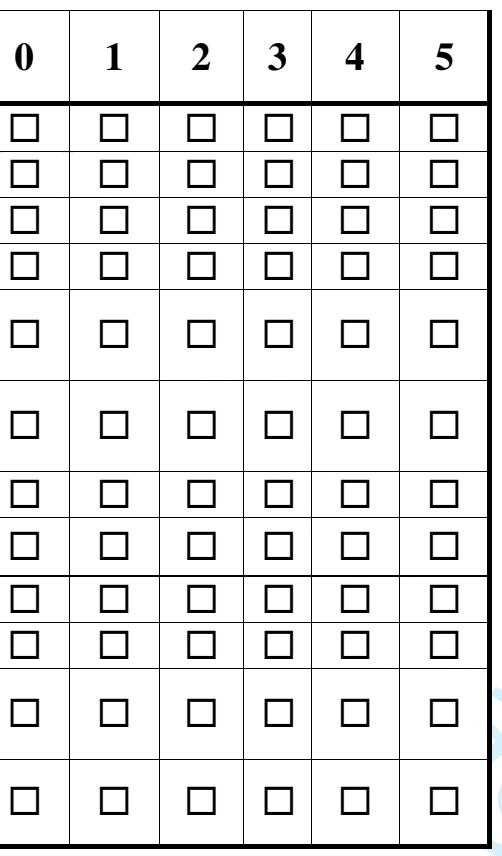

Pls. return by email, fax or mail.

http://mc.manuscriptcentral.com/ecaam

(ㄱ) Yu et al. (2015) 


\begin{tabular}{|c|c|c|c|c|c|c|}
\hline $\begin{array}{l}\text { 11. Please rate the relative frequency of the following threats of } \\
\text { Sustainability integrating into VM }\end{array}$ & $\mathbf{0}$ & 1 & 2 & 3 & 4 & 5 \\
\hline a) Client's strategic planning do not incorporating sustainability objectives & $\square$ & $\square$ & $\square$ & $\square$ & $\square$ & $\square$ \\
\hline $\begin{array}{l}\text { b) Passive reaction by the client and service provider for fulfilling } \\
\text { environmental and social needs }\end{array}$ & $\square$ & $\square$ & $\square$ & $\square$ & $\square$ & $\square$ \\
\hline c) Belief that trade-off requirements among the principles of sustainability & $\square$ & $\square$ & $\square$ & $\square$ & $\square$ & $\square$ \\
\hline d) Perceived additional time required for sustainable measures & $\square$ & $\square$ & $\square$ & $\square$ & $\square$ & $\square$ \\
\hline e) Negative perception of green buildings in terms of additional cost & $\square$ & $\square$ & $\square$ & $\square$ & $\square$ & $\square$ \\
\hline $\begin{array}{l}\text { f) Strong perception that integration of sustainability issues into VM studies } \\
\text { may slow down the progress of the studies }\end{array}$ & $\square$ & $\square$ & $\square$ & $\square$ & $\square$ & $\square$ \\
\hline $\begin{array}{l}\text { g) Lack of knowledge, understanding and importance of sustainable } \\
\text { development }\end{array}$ & $\square$ & $\square$ & $\square$ & $\square$ & $\square$ & $\square$ \\
\hline $\begin{array}{l}\text { h) VM facilitator's fear of extra responsibilities for highlighting importance } \\
\text { of sustainable development }\end{array}$ & $\square$ & $\square$ & $\square$ & $\square$ & $\square$ & $\square$ \\
\hline $\begin{array}{l}\text { i) Ignoring VM facilitator recommendations for achieving sustainability } \\
\text { objectives due to clients' limited budget or other prior commitments }\end{array}$ & $\square$ & $\square$ & $\square$ & $\square$ & $\square$ & $\square$ \\
\hline $\begin{array}{l}\text { j) No end users' involvement in sustainable design and development } \\
\text { process }\end{array}$ & $\square$ & $\square$ & $\square$ & $\square$ & $\square$ & $\square$ \\
\hline $\begin{array}{l}\text { k) No compulsory regulations for implementing sustainable development } \\
\text { measures, implementation is only an option }\end{array}$ & $\square$ & $\square$ & $\square$ & $\square$ & $\square$ & $\square$ \\
\hline $\begin{array}{l}\text { 1) Corporate image could be damaged for not implementing sustainable } \\
\text { practices }\end{array}$ & $\square$ & $\square$ & $\square$ & $\square$ & $\square$ & $\square$ \\
\hline m) Others, pls. specify: & $\square$ & $\square$ & $\square$ & $\square$ & $\square$ & $\square$ \\
\hline
\end{tabular}

\section{Further comments on Integration of Sustainability into VM}

Please return the completed questionnaire to Dr. Ann Yu, Department of Building and Real Estate, The Hong Kong Polytechnic University, Hung Hom, Kowloon, Hong Kong, by post, email ann.yu@ polyu.edu.hk, or fax: (852) 2764 5131.

If you are interested in receiving the overall results, please provide the following details:

\begin{tabular}{|c|c|}
\hline Name: & Position: \\
\hline \multicolumn{2}{|l|}{ Organization: } \\
\hline \multicolumn{2}{|l|}{ Address: } \\
\hline Telephone No.: & Email address: \\
\hline
\end{tabular}

**End of questionnaire**

Thank you for your cooperation! 


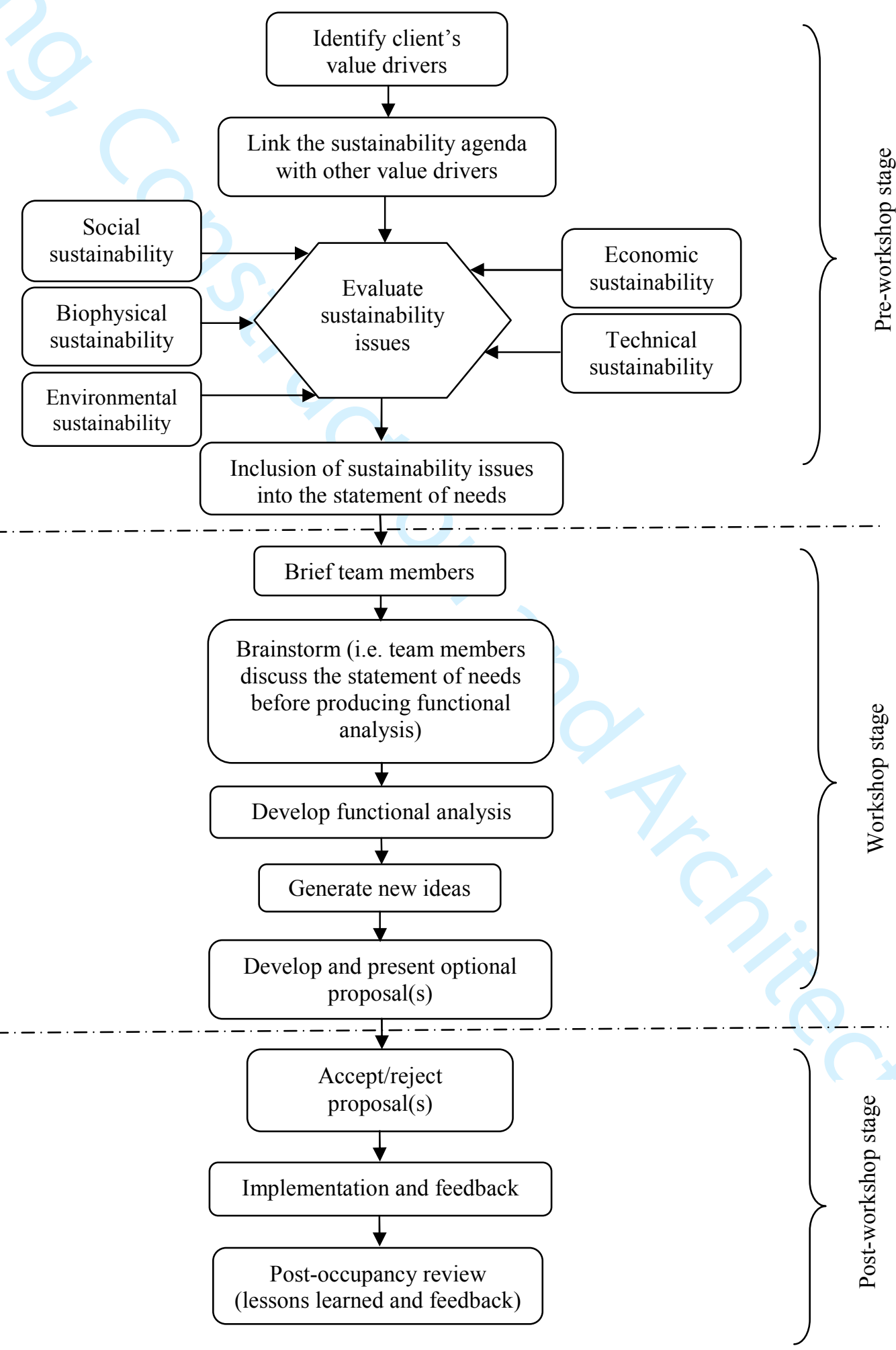

Figure 1: Stages of integration of sustainability into value management process (adapted from Abidin and Pasquire 2007) 
Table 1. Operationalization of constructs

\section{VM Attributes}

References

VM provides opportunities for multidisciplinary professionals and stakeholders to become involved and focus on issues relating to society and the environment

Stakeholders are strongly encouraged to propose sustainable solutions at an early stage

An effective VM process allows sustainability measures to be integrated during the conceptual and early design stages

The strategic timing of the VM process enables the sustainability agenda to be highlighted at a

critical decision-making stage

The VM workshops provide diverse knowledge sources for sustainable development

The VM workshops recommend solutions for energy- and resource-efficient buildings

Long-term proposal criteria, such as adaptability for future changes, whole-life costs and select

renewable resources, are considered during VM exercises

VM promotes sustainable project design

The optimum use of natural resources is recommended

During VM studies, solutions are proposed that promote a safe and healthy environment for the occupants

The lack of well-trained staff and expertise of VM participants in relation to sustainable development

The lack of client support in achieving sustainable construction during the VM exercise

Unclear project briefs, poor specifications or inadequate business cases for achieving sustainable

development

The lack of incentives for clients/contractors to achieve sustainable development goals

The additional management and operational costs of sustainability measures for the project

The lack of legal government enforcement of sustainability policies

The difficulty of enforcing environmental performance

The lack of contractor, sub-contractor and supplier cooperation in achieving sustainability goals The VM facilitator and/or client does not highlight the role of corporate social responsibility in achieving the environmental and sustainable needs of society during the VM process

The lack of sustainability integration into VM studies

The lack of sustainable construction guidance

The lack of technological support for achieving sustainability objectives

Encouraging the reduction, reuse and recycling of construction and demolition waste

The VM process encourages the application of environmentally friendly technologies on site

Promoting the client's interest in sustainability as a primary value driver

Including sustainability issues in the VM practices early on

VM is a mechanism proved capable of delivering better sustainable value

Highlighting the financial and non-financial incentives of sustainable development for clients and contractors during VM studies

Establishing a waste management plan during VM exercises

Introducing sustainability guidance for VM practitioners

Including environmental scoring in the tender process

Providing in-house training for environmental management

The legal enforcement of environmental protection and the implementation of sustainable practices

The perceived additional time required for sustainable measures

The client and service provider react passively in fulfilling environmental and social needs

The belief that the principles of sustainability should require trade-offs

ङु The strong perception that integrating sustainability issues into VM studies may slow down their progress

The negative perception of green buildings in terms of the additional cost involved

The client's strategic planning does not incorporate sustainability objectives

(Shen and Yu 2012)

(Fewing 2005)

(Ramly et al. 2015)

(Shen and Yu 2012)

(Tahir et al. 2016)

(Fewing 2005)

(Yeomans 2002)

(Better Buildings Summit

2003)

(Yates 2003)

(Al-Saleh and Taleb 2010)

(Oke and Aigbavboa 2017)

(Al-Saleh and Taleb 2010)

(Organisation for

Economic Co-operation

and Development 2010)

(Al-Saleh and Taleb 2010)

(Oke and Aigbavboa 2017)

(Abidin and Pasquire

2005; Abidin and Pasquire

2007)

(Al-Saleh and Taleb 2010)

(Abidin and Pasquire

2005)

(Abidin and Pasquire

2005; Fewing 2005)

(Abidin and Pasquire

2005)

(Fewing 2005)

(Abidin and Pasquire 2005)

(Al-Saleh and Taleb 2010)

(Abidin 2005)

(Shen and Yu 2012)

(Shen et al. 2015)

(Shen and Yu 2012)

(Abidin and Pasquire

2005) 
Ignoring the VM facilitator's recommendations for achieving sustainability objectives due to the client's limited budget or other prior commitments

The organization's corporate image could be damaged due to its failure to implement sustainable practices

The end users' lack of involvement in the sustainable design and development process

The lack of knowledge and understanding of the importance of sustainable development

The lack of compulsory regulations for implementing sustainable development measures, and the status of implementation as an option

The VM facilitator's fear of the extra responsibilities involved in highlighting the importance of sustainable development
(Oke and Aigbavboa 2017)

(Pitt et al. 2009)

(Williams and Dair 2007)

(Shen and Yu 2012) 
Table 2. Test of Cronbach's alpha

\begin{tabular}{ccc}
\hline Question number & $N$ & Cronbach's alpha \\
\hline 8 & 10 & 0.920 \\
9 & 12 & 0.923 \\
10 & 11 & 0.891 \\
11 & 12 & 0.862 \\
\hline Note: $N=$ number of items in each survey question
\end{tabular}

Note: $N=$ number of items in each survey question 
Table 3. Test of concordance for sustainability and VM survey

\begin{tabular}{ccccccc}
\hline $\begin{array}{c}\text { Question } \\
\text { number }\end{array}$ & $N$ & $\begin{array}{c}\text { Chi-square } \\
\chi^{2}\end{array}$ & $\begin{array}{c}\text { df } \\
\text { level from SPSS } \\
\text { output }\end{array}$ & $\begin{array}{c}\text { Critical value of } \\
\text { Chi-square } \chi^{2} \text { at } \\
\text { a }=0.001\end{array}$ & Null hypothesis \\
\hline 8 & 10 & 63.805 & 9 & $<0.001$ & 27.87 & $\mathrm{R}$ \\
9 & 12 & 31.850 & 11 & $<0.001$ & 31.26 & $\mathrm{R}$ \\
10 & 11 & 20.898 & 10 & $<0.001$ & 29.59 & $\mathrm{~A}$ \\
11 & 12 & 29.099 & 11 & $<0.001$ & 31.26 & $\mathrm{~A}$ \\
\hline
\end{tabular}

Note: Total sample size $=73 ; N=$ number of items in each question; $\mathrm{df}=$ degree of freedom; $\mathrm{A}=$ accept; $\mathrm{R}=$ reject. 
Table 4. Descriptive statistics of the SWOT attributes of integrating sustainability into the VM process

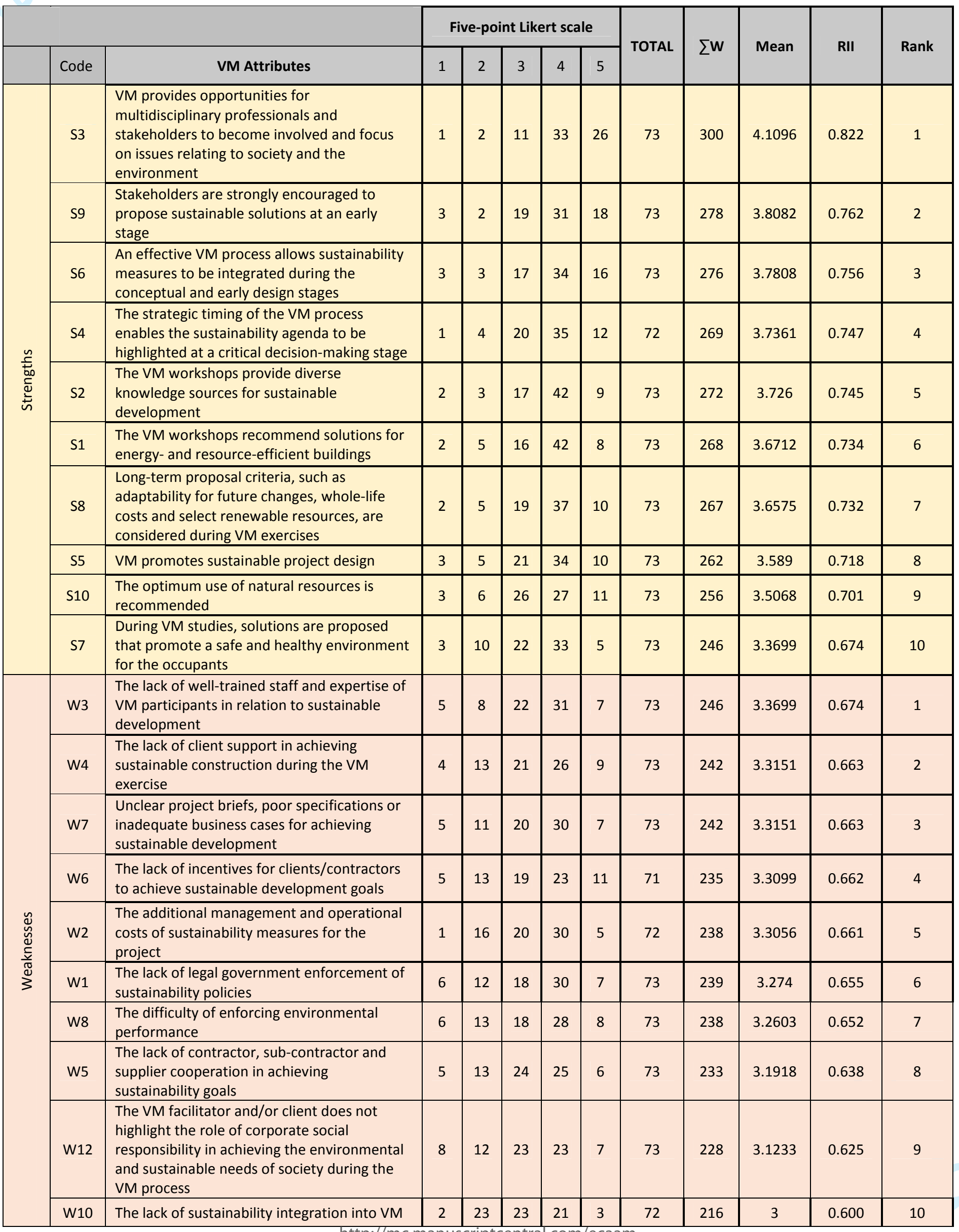




\begin{tabular}{|c|c|c|c|c|c|c|c|c|c|c|c|c|}
\hline & & studies & & & & & & & & & & \\
\hline & W11 & The lack of sustainable construction guidance & 6 & 17 & 23 & 23 & 3 & 72 & 216 & 3 & 0.600 & 11 \\
\hline & W9 & $\begin{array}{l}\text { The lack of technological support for } \\
\text { achieving sustainability objectives }\end{array}$ & 9 & 24 & 18 & 21 & 1 & 73 & 200 & 2.7397 & 0.548 & 12 \\
\hline \multirow{11}{*}{ 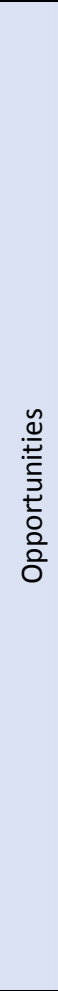 } & 06 & $\begin{array}{l}\text { Encouraging the reduction, reuse and } \\
\text { recycling of construction and demolition } \\
\text { waste }\end{array}$ & 1 & 3 & 12 & 45 & 12 & 73 & 283 & 3.8767 & 0.775 & 1 \\
\hline & 07 & $\begin{array}{l}\text { The VM process encourages the application of } \\
\text { environmentally friendly technologies on site }\end{array}$ & 1 & 1 & 17 & 41 & 13 & 73 & 283 & 3.8767 & 0.775 & 2 \\
\hline & O3 & $\begin{array}{l}\text { Promoting the client's interest in } \\
\text { sustainability as a primary value driver }\end{array}$ & 1 & 8 & 12 & 31 & 21 & 73 & 282 & 3.863 & 0.773 & 3 \\
\hline & 01 & $\begin{array}{l}\text { Including sustainability issues in the VM } \\
\text { practices early on }\end{array}$ & 1 & 3 & 18 & 36 & 15 & 73 & 280 & 3.8356 & 0.767 & 4 \\
\hline & 04 & $\begin{array}{l}\text { VM is a mechanism proved capable of } \\
\text { delivering better sustainable value }\end{array}$ & 2 & 1 & 18 & 43 & 9 & 73 & 275 & 3.7671 & 0.753 & 5 \\
\hline & 011 & $\begin{array}{l}\text { Highlighting the financial and non-financial } \\
\text { incentives of sustainable development for } \\
\text { clients and contractors during VM studies }\end{array}$ & 2 & 3 & 18 & 39 & 11 & 73 & 273 & 3.7397 & 0.748 & 6 \\
\hline & 09 & $\begin{array}{l}\text { Establishing a waste management plan during } \\
\text { VM exercises }\end{array}$ & 0 & 2 & 30 & 30 & 11 & 73 & 269 & 3.6849 & 0.737 & 7 \\
\hline & $\mathrm{O} 2$ & $\begin{array}{l}\text { Introducing sustainability guidance for VM } \\
\text { practitioners }\end{array}$ & 1 & 6 & 21 & 32 & 13 & 73 & 269 & 3.6849 & 0.737 & 8 \\
\hline & 010 & $\begin{array}{l}\text { Including environmental scoring in the tender } \\
\text { process }\end{array}$ & 1 & 7 & 21 & 32 & 12 & 73 & 266 & 3.6438 & 0.729 & 9 \\
\hline & 08 & $\begin{array}{l}\text { Providing in-house training for environmental } \\
\text { management }\end{array}$ & 1 & 3 & 26 & 36 & 7 & 73 & 264 & 3.6164 & 0.723 & 10 \\
\hline & 05 & $\begin{array}{l}\text { The legal enforcement of environmental } \\
\text { protection and the implementation of } \\
\text { sustainable practices }\end{array}$ & 2 & 5 & 25 & 32 & 9 & 73 & 260 & 3.5616 & 0.712 & 11 \\
\hline \multirow{12}{*}{ 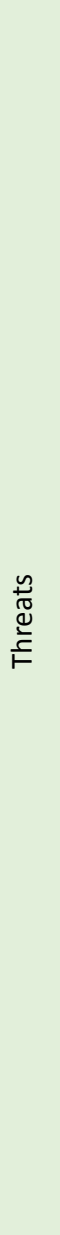 } & T4 & $\begin{array}{l}\text { The perceived additional time required for } \\
\text { sustainable measures }\end{array}$ & 1 & 12 & 13 & 37 & 10 & 73 & 262 & 3.589 & 0.718 & 1 \\
\hline & $\mathrm{T} 2$ & $\begin{array}{l}\text { The client and service provider react passively } \\
\text { in fulfilling environmental and social needs }\end{array}$ & 2 & 8 & 14 & 44 & 5 & 73 & 261 & 3.5753 & 0.715 & 2 \\
\hline & T3 & $\begin{array}{l}\text { The belief that the principles of sustainability } \\
\text { should require trade-offs }\end{array}$ & 3 & 11 & 22 & 29 & 8 & 73 & 247 & 3.3836 & 0.677 & 3 \\
\hline & T6 & $\begin{array}{l}\text { The strong perception that integrating } \\
\text { sustainability issues into VM studies may slow } \\
\text { down their progress }\end{array}$ & 4 & 9 & 23 & 30 & 7 & 73 & 246 & 3.3699 & 0.674 & 4 \\
\hline & T5 & $\begin{array}{l}\text { The negative perception of green buildings in } \\
\text { terms of the additional cost involved }\end{array}$ & 3 & 8 & 21 & 32 & 9 & 73 & 255 & 3.4932 & 0.699 & 5 \\
\hline & $\mathrm{T} 1$ & $\begin{array}{l}\text { The client's strategic planning does not } \\
\text { incorporate sustainability objectives }\end{array}$ & 1 & 11 & 23 & 27 & 11 & 73 & 255 & 3.4932 & 0.699 & 6 \\
\hline & T9 & $\begin{array}{l}\text { Ignoring the VM facilitator's } \\
\text { recommendations for achieving sustainability } \\
\text { objectives due to the client's limited budget } \\
\text { or other prior commitments }\end{array}$ & 3 & 12 & 22 & 29 & 7 & 73 & 244 & 3.3425 & 0.668 & 7 \\
\hline & T12 & $\begin{array}{l}\text { The organization's corporate image could be } \\
\text { damaged due to its failure to implement } \\
\text { sustainable practices }\end{array}$ & 2 & 9 & 29 & 29 & 4 & 73 & 243 & 3.3288 & 0.666 & 8 \\
\hline & $\mathrm{T} 10$ & $\begin{array}{l}\text { The end users' lack of involvement in the } \\
\text { sustainable design and development process }\end{array}$ & 3 & 13 & 22 & 28 & 7 & 73 & 242 & 3.3151 & 0.663 & 9 \\
\hline & T7 & $\begin{array}{l}\text { The lack of knowledge and understanding of } \\
\text { the importance of sustainable development }\end{array}$ & 4 & 15 & 17 & 29 & 8 & 73 & 241 & 3.3014 & 0.660 & 10 \\
\hline & $\mathrm{T} 11$ & $\begin{array}{l}\text { The lack of compulsory regulations for } \\
\text { implementing sustainable development } \\
\text { measures, and the status of implementation } \\
\text { as an option }\end{array}$ & 4 & 10 & 27 & 25 & 7 & 73 & 240 & 3.2877 & 0.658 & 11 \\
\hline & T8 & $\begin{array}{l}\text { The VM facilitator's fear of the extra } \\
\text { responsibilities involved in highlighting the } \\
\text { importance of sustainable development }\end{array}$ & 7 & 21 & 22 & 16 & 7 & 73 & 214 & 2.9315 & 0.586 & 12 \\
\hline
\end{tabular}


Table 5. Statistically significant Mann Whitney $U$-test results for integrating sustainability into the VM process

\begin{tabular}{|c|c|c|c|c|}
\hline \multirow{2}{*}{$\begin{array}{l}\text { Question } \\
\text { number }\end{array}$} & \multirow{2}{*}{$\begin{array}{l}\text { SWOT analysis attributes of integrating } \\
\text { sustainability into the VM process }\end{array}$} & $\begin{array}{l}\text { Client and VM } \\
\text { facilitator }\end{array}$ & $\begin{array}{l}\text { Client and VM } \\
\text { participants }\end{array}$ & $\begin{array}{l}\text { VM facilitator and } \\
\text { participants }\end{array}$ \\
\hline & & $\begin{array}{c}p \text { at } \\
\alpha=0.05\end{array}$ & $\begin{array}{c}p \text { at } \\
\alpha=0.05\end{array}$ & $\begin{array}{c}p \text { at } \\
\alpha=0.05\end{array}$ \\
\hline $8(d)$ & $\begin{array}{l}\text { The strategic timing of the VM process enables } \\
\text { the sustainability agenda to be highlighted at a } \\
\text { critical decision-making stage }\end{array}$ & $.030^{*}$ & - & $.003^{*}$ \\
\hline $8(\mathrm{f})$ & $\begin{array}{l}\text { An effective VM process allows sustainability } \\
\text { measures to be integrated during the conceptual } \\
\text { and early design stages }\end{array}$ & - & $.021^{*}$ & $.001^{*}$ \\
\hline $8(\mathrm{~g})$ & $\begin{array}{l}\text { During VM studies, solutions are proposed that } \\
\text { promote a safe and healthy environment for the } \\
\text { occupants }\end{array}$ & - & - & $.016^{*}$ \\
\hline 8(h) & $\begin{array}{l}\text { Long-term proposal criteria, such as } \\
\text { adaptability for future changes, whole-life costs } \\
\text { and select renewable resources, are considered } \\
\text { during VM exercises }\end{array}$ & - & - & $.027^{*}$ \\
\hline 9(i) & $\begin{array}{l}\text { The lack of technological support for achieving } \\
\text { sustainability objectives }\end{array}$ & - & $.031^{*}$ & - \\
\hline $10(d)$ & $\begin{array}{l}\mathrm{VM} \text { is a mechanism proved capable of } \\
\text { delivering better sustainable value }\end{array}$ & - & - & $.017^{*}$ \\
\hline $10(\mathrm{~g})$ & $\begin{array}{l}\text { The VM process encourages participants to } \\
\text { apply environmentally friendly technologies on } \\
\text { site }\end{array}$ & - & - & $.048^{*}$ \\
\hline $11(\mathrm{~d})$ & $\begin{array}{l}\text { The perceived additional time required for } \\
\text { sustainable measures }\end{array}$ & - & $.045^{*}$ & - \\
\hline 11(e) & $\begin{array}{l}\text { The negative perception of green buildings in } \\
\text { terms of the additional cost involved }\end{array}$ & - & $.014^{*}$ & $.018^{*}$ \\
\hline 11(i) & $\begin{array}{l}\text { Ignoring the VM facilitator's recommendations } \\
\text { for achieving sustainability objectives due to } \\
\text { the clients' limited budgets or other prior } \\
\text { commitments }\end{array}$ & - & - & $.038^{*}$ \\
\hline
\end{tabular}


Table 6. Statistically significant Kruskal-Wallis test results

\begin{tabular}{clcc}
\hline $\begin{array}{c}\text { Question } \\
\text { number }\end{array}$ & $\begin{array}{l}\text { SWOT analysis attributes of integrating sustainability into the VM } \\
\text { process }\end{array}$ & $\chi^{2}$ & $p$-value \\
\hline $8(\mathrm{~d})$ & $\begin{array}{l}\text { The strategic timing of the VM process enables the sustainability } \\
\text { agenda to be highlighted at a critical decision-making stage }\end{array}$ & 10.038 & $.007^{*}$ \\
\hline $8(\mathrm{f})$ & $\begin{array}{l}\text { An effective VM process allows sustainability measures to be } \\
\text { integrated during the conceptual and early design stages }\end{array}$ & 13.218 & $.001^{*}$ \\
\hline $\begin{array}{l}\text { VM is a mechanism proved capable of delivering better sustainable } \\
\text { value }\end{array}$ & 6.193 & $.045^{*}$ \\
\hline $\begin{array}{l}\text { The negative perception of green buildings in terms of the additional } \\
\text { cost involved }\end{array}$ & 9.507 & $.009^{*}$ \\
\hline $\begin{array}{l}\text { Notes: *Significant difference at the 95\% confidence level. Asymp. Sig. (2 tailed) Total sample size=73 (clients=13, VM facilitators=19, VM } \\
\text { participants team members=41). }\end{array}$
\end{tabular}


Table 7. Descriptive statistics of the SWOT attributes of integrating sustainability into the VM process (mean values)

\begin{tabular}{lccccc}
\hline $\begin{array}{l}\text { SWOT } \\
\text { attributes }\end{array}$ & Clients & VM facilitators & VM participants & $\begin{array}{c}\text { Overall mean } \\
\text { values }\end{array}$ & RII \\
\hline Strengths & 3.80 & 4.00 & 3.50 & 3.70 & 0.739 \\
\hline Weaknesses & 3.39 & 3.12 & 3.13 & 3.17 & 0.637 \\
\hline Opportunities & 3.88 & 3.84 & 3.63 & 3.73 & 0.748 \\
\hline Threats & 3.61 & 3.23 & 3.34 & 3.36 & 0.674 \\
\hline
\end{tabular}

